(C) The Authors 2019. This is an Open Access article, distributed under the terms of the Creative Commons Attribution licence (http:// creativecommons.org/licenses/by/4.0/), which permits unrestricted re-use, distribution, and reproduction in any medium, provided the original work is properly cited.

\title{
Dairy foods and bone health throughout the lifespan: a critical appraisal of the evidence
}

\author{
Sandra Iuliano ${ }^{1 *}$ and Tom R. Hill ${ }^{2}$ \\ ${ }^{1}$ Department of Endocrinology, University of Melbourne/Austin Health, Heidelberg, VIC 3084, Australia \\ ${ }^{2}$ Institute of Cellular Medicine and Human Nutrition Research Centre, Newcastle University, \\ Newcastle-Upon-Tyne NE2 4HH, UK \\ (Submitted 25 July 2018 - Final revision received 16 November 2018 - Accepted 15 December 2018 - First published online 14 January 2019$)$
}

\section{Abstract}

The consumption of high-Ca, high-protein dairy foods (i.e. milk, cheese, yogurt) is advocated for bone health across the lifespan to reduce the risk of low-trauma fractures. However, to date, the anti-fracture efficacy of dairy food consumption has not been demonstrated in randomised controlled trials but inferred from cross-sectional and prospective studies. The anti-fracture efficacy of dairy food consumption is plausible, but testing this requires a robust study design to ensure outcomes are suitably answering this important public health question. The evidence of skeletal benefits of dairy food consumption is equivocal, not because it may not be efficacious but because the study design and execution are often inadequate. The key issues are compliance with dietary intervention, dropouts, sample sizes and most importantly lack of deficiency before intervention. Without careful appraisal of the design and execution of available studies, precarious interpretations of outcomes may be made from these poorly designed or executed studies, without consideration of how study design may be improved. Dairy food interventions in children are further hampered by heterogeneity in growth: in particular sex and maturity-related differences in the magnitude, timing, location and surfacespecific site of bone accrual. Outcomes of studies combining children of different sexes and maturity status may be masked or exaggerated by these differences in growth, so inaccurate conclusions are drawn from results. Until these critical issues in study design are considered in future dairy food interventions, the anti-fracture efficacy of dairy food consumption may remain unknown and continue to be based on conjecture.

\section{Key words: Bone: Critical reviews: Dairy food: Research design}

Dairy foods, namely, milk, cheese and yogurt, are the principal sources of dietary $\mathrm{Ca}$ in developed countries, with an adequate consumption synonymous with optimal bone health. Evidence from observational and prospective studies supports this notion and is highly suggestive of this association; however, the most convincing proof of efficacy comes from well-designed randomised controlled studies. Equally, the association between fracture risk reduction and the consumption of dairy foods is also acquired from observational, case-control and prospective studies; but in the case of anti-fracture efficacy of dairy food consumption, this evidence is lacking, as these trials have not been reported. The aim of this narrative review is to critique the available evidence on dairy food consumption and bone health over the lifespan, with an emphasis on the importance of study design and execution.

\section{Method of data acquisition}

A literature search was conducted on PubMed database between February and December 2017. The following
Medical Subject Headings terms were used to identify randomised controlled studies of dairy foods: 'dairy' or 'milk' or 'cheese' or 'yoghurt' or 'dietary calcium' or 'calcium-rich food' and bone; 'bone'. The two searches were combined with the term 'randomized' or 'randomised', resulting in the identification of 2087 journal articles. Following the removal of duplicates, the exclusion criteria of (i) animal studies, (ii) non-randomised trial, (iii) not a dairy food-based intervention, (iv) non-English articles and (v) bone-related measures not being a primary outcome were applied. The remaining full-text articles were reviewed and a manual search of reference lists conducted to identify any additional articles. Of the fifty-five remaining articles, an additional exclusion criteria of 'dairy products used intentionally as a vehicle for nutrient delivery (e.g. vitamin K)' was applied. Articles reporting interim or follow-up outcomes from the same study were also removed. These articles are mentioned but not discussed in detail in the following critical appraisal of the literature.

Abbreviations: BMC, bone mineral content; BMD, bone mineral density; CTX, C-terminal telopeptide of type 1 collagen; IGF-1, insulin-like growth factor-1; PBM, peak bone mass

* Corresponding author: Dr S. Iuliano, fax +6139496 3365, email sandraib@unimelb.edu.au 
Growth, bone structure and dairy food interventions: trying to hit a moving target

The lower fracture rates observed in elderly men compared with women may, in part, have their origins in sex differences in bone morphology from early in life. Males are born with a larger skeleton compared with females, implicating the potential of genetic or intrauterine factors in producing sex differences ${ }^{(1)}$. Higher testosterone levels have been measured in cord blood of newborn males, with levels peaking between 1 and 3 months, then decreasing to prepubertal levels by 7 months, compared with females in whom testosterone levels decline soon after birth to resemble prepubertal levels by 1 month $^{(2,3)}$.

In both sexes, growth in crown-heel length is rapid soon after birth, slows within the first year then re-accelerates after 12 months of age ${ }^{(4)}$. However, this early growth is regionspecific. Appendicular growth velocity accelerates, while axial growth continues at a slower rate. Before puberty, longitudinal growth does not differ by sex, which may suggest a common effector for both sexes, such as insulin-like growth factor-1 $(\mathrm{IGF}-1)^{(5)}$. At puberty when sex hormone levels rise, appendicular growth velocity declines while axial growth velocity accelerates $^{(6)}$. So while the patterns of longitudinal growth are similar between the sexes, puberty occurs approximately 2 years earlier in females than in males. Males have longer legs but differ less from females in trunk length because of their longer period of prepubertal (appendicular) growth.

Greater bone width favouring males has been observed as early as 3 months of age $e^{(1)}$. Prepubertal male twins have a $5 \%$ larger mid-femur cross-sectional area than their female co-twin that confers a $12 \%$ greater resistance to bending, despite no difference in body weight. By the end of maturity in boy-girl twins, bending strength at the mid-femur is 3-fold greater in males compared with females but males are also heavier ${ }^{(7)}$. At puberty, in males, the outer (periosteal) surface continues to widen, while expansion of the inner (endosteal) surface slows then ceases to widen, resulting in thickening of the cortex but further from the central axis of the bone. In females, the expansion of the outer bone surface slows then ceases, while apposition occurs on the inner (endosteal) surface, also resulting in thickening of the cortex, but in a narrower bone that is closer to the central axis. Androgens, growth hormones and IGF-1 stimulate periosteal expansion in males, while oestrogen inhibits expansion but stimulates endosteal apposition in females. The differences in linear and radial growth velocities by region, sex and age, and sex differences in age of maturity indicate that nutritional factors that may promote bone growth will have differing effects depending on the timing and duration of exposure.

\section{Dairy foods, calcium and bone growth in children and adolescents}

Dairy foods are the main source of Ca during growth, with between one- and two-thirds of $\mathrm{Ca}$ obtained from dairy products $^{(8,9)}$. Despite variations in dietary recommendations for $\mathrm{Ca}$ intake in children, an insufficient intake of $\mathrm{Ca}$ is likely in the absence of dairy food, unless fortified foods or supplements are consumed. Gao et al. ${ }^{(10)}$ used data from over 2000 adolescents from the National Health and Nutrition Examination Survey study and modelled dietary intake aligned to the guidelines, with and without dairy foods, and observed that adequate $\mathrm{Ca}$ was not achievable with regular food without the inclusion of dairy food and was only possible if Ca-fortified foods were consumed. In the USA, for children aged 2-18 years, the average $\mathrm{Ca}$ intake is approximately $950 \mathrm{mg} / \mathrm{d}$ of which $32-51 \%$ is obtained directly from milk and cheese, thus emphasising the role of dairy foods as the principal dietary source of $\mathrm{Ca}^{(11)}$.

A limited number of randomised studies investigated the effect of dairy food consumption on bone accrual during growth ( $n$ 12) $(\text { Table } 1)^{(12-23)}$. Amongst these studies issues of varying maturity levels of participants, adequate baseline $\mathrm{Ca}$ intakes, poor compliance and high dropout cloud interpretation of results highlight the challenges of interventions involving children.

Identifying bone accrual resulting from puberty from that due to dairy food supplementation is challenging. Peak bone mineral accrual during growth may be as high as $400 \mathrm{~g} /$ year in males and $300 \mathrm{~g} /$ year in females, significantly more than what may be achievable with 1 year of dairy food supplementation $^{(24)}$. Of the twelve studies, eleven did not control for Tanner staging (as a measure of sexual maturity) or failed to report Tanner staging before or after intervention, making it difficult to quantify the skeletal gains due to dairy food supplementation. For example, in a 24-month randomised study involving 195, 10-12-year-old girls, Cheng et al. ${ }^{(18)}$ observed greater thickening of the cortex at the mid-tibia in girls who were $>50 \%$ compliant when assigned to cheese (providing approximately $1000 \mathrm{mg} \mathrm{Ca}$ ) compared with $\mathrm{Ca}+$ vitamin D, Ca alone or placebo, but no group differences were observed for crosssectional area of the tibia, suggesting bone accrual on the inner surface; a characteristic of puberty. At baseline, groups were not matched for pubertal status, and Tanner staging not reported at study end. When growth velocity was accounted for, treatment effects were no longer evident. The authors acknowledged the diversity of growth velocities likely masks the effect of supplementation as children transition through puberty.

Studies involving similarly aged males and females further exacerbate the potential for puberty to mask any benefits of dairy food supplementation. While sex differences in growth before puberty are negligible, females commence puberty about 2 years earlier than males do, so the earlier age of onset is accompanied by maturity-related acceleration in bone accrual. Iuliano-Burns et al. ${ }^{(14)}$ randomised ninety-nine prepubertal children aged 5-11 years to 10 months of supplementation of $800 \mathrm{mg}$ Ca daily from milk minerals, calcium carbonate or placebo, with a 12-month follow-up after supplementation. The greater gains in bone mineral content (BMC) at the pelvis in both treatment groups were not sustained after adjustment for multiple comparisons. However, when data were confined to those who remained prepubertal for the duration of the project, children assigned to the two treatment groups (milk minerals: $n$ 25, calcium carbonate: $n$ 30) accrued $8 \%$ more BMC at the pelvis than controls ( $n$ 19), with the benefits still evident in the milk mineral group 12 months after discontinuation ${ }^{(14)}$. Changes to $\mathrm{Ca}$ absorption during maturation may further confound outcomes ${ }^{(25,26)}$.

Skeletal benefits of dairy food supplementation are unlikely if baseline $\mathrm{Ca}$ is sufficient. Of the twelve studies, seven included 
Table 1. Summary of study characteristics and the main strengths and limitations of randomised dairy food-based interventions across the lifespan

\begin{tabular}{|c|c|c|c|}
\hline Reference & Study characteristics & Strengths & Limitations \\
\hline \multicolumn{4}{|l|}{ Growth } \\
\hline Zhu et al. $(2008)^{(12)}$ & $\begin{array}{l}n 345 \text { boys and girls aged } 10 \text { years } \\
\text { Milk }(\mathrm{Ca}) / \mathrm{milk}(\mathrm{Ca}+\text { vitamin } \mathrm{D}) / \text { placebo } \\
2 \text { years }\end{array}$ & Dietary $\mathrm{Ca}<700 \mathrm{mg} / \mathrm{d}$ & $\begin{array}{l}\text { Pubertal status not reported } \\
\text { Compliance not reported }\end{array}$ \\
\hline Gibbons et al. $(2004)^{(13)}$ & $\begin{array}{l}n 154 \text { boys and girls aged } 8-10 \text { years } \\
\text { Milk powder/placebo } \\
18 \text { months }\end{array}$ & $\begin{array}{l}80 \% \text { compliance (in those who } \\
\text { completed) }\end{array}$ & $\begin{array}{l}\text { Baseline } \mathrm{Ca}>900 \mathrm{mg} / \mathrm{d} \\
>50 \% \text { withdrew }\end{array}$ \\
\hline Iuliano-Burns et al. (2006) $)^{(14)}$ & $\begin{array}{l}n 99 \text { boys and girls aged } 5-11 \text { years } \\
\text { Fortified foods (milk minerals)/placebo } \\
10 \text { months }\end{array}$ & $80 \%$ compliance & $\begin{array}{l}\text { Dietary } \mathrm{Ca}>700 \mathrm{mg} / \mathrm{d} \\
\text { Small number of prepubertal } \\
\text { children remaining }\end{array}$ \\
\hline Du et al. $(2004)^{(15)}$ & n 757 girls aged 10 years & Dietary $\mathrm{Ca}<700 \mathrm{mg} / \mathrm{d}$ & Dietary intake of milk reduced \\
\hline & $\begin{array}{l}\text { Milk }(\mathrm{Ca}) / \text { milk (vitamin } \mathrm{D}) / \text { placebo } \\
2 \text { years }\end{array}$ & $100 \%$ compliance & Uneven distribution of maturity levels \\
\hline Lau et al. $(2004)^{(16)}$ & $\begin{array}{l}n 324 \text { boys and girls aged } 10 \text { years } \\
\text { Milk powder: } 80 \mathrm{~g} \text { or } 40 \mathrm{~g} / \text { placebo } \\
18 \text { months }\end{array}$ & $\begin{array}{l}\text { Dietary Ca }<500 \mathrm{mg} / \mathrm{d} \\
\text { School-based compliance } 100 \%\end{array}$ & $\begin{array}{l}\text { Pubertal status not reported at } \\
\text { follow-up } \\
\text { Compliance only reported for one } \\
\text { group }\end{array}$ \\
\hline Chevalley et al. $2005^{(17)}$ & $\begin{array}{l}n 235 \text { prepubertal boys aged } 6-9 \text { years } \\
\text { Milk minerals (in food)/placebo } \\
12 \text { months }\end{array}$ & $\begin{array}{l}\text { Single maturity level at baseline } \\
98 \% \text { compliance }\end{array}$ & $\begin{array}{l}\text { Dietary } \mathrm{Ca}>700 \mathrm{mg} / \mathrm{d} \\
\text { Summed bone mineral density } \\
\text { changes from all five sites }\end{array}$ \\
\hline Cheng et al. $(2005)^{(18)}$ & $\begin{array}{l}\text { Girls aged } 10-12 \text { years } \\
\mathrm{Ca}+\text { vitamin } \mathrm{D} / \text { cheese/placebo } \\
2 \text { years }\end{array}$ & $\begin{array}{l}70 \% \text { compliance } \\
\text { Dietary } \mathrm{Ca}<700 \mathrm{mg} / \mathrm{d}\end{array}$ & $\begin{array}{l}\text { Uneven distribution of pubertal } \\
\text { status } \\
\text { Approximately } 1 / 3 \text { not followed up }\end{array}$ \\
\hline Bonjour et al. (1997) ${ }^{(19)}$ & $\begin{array}{l}n 149 \text { girls aged } 6-9 \text { years } \\
\text { Milk minerals (in food)/placebo } \\
48 \text { weeks }\end{array}$ & $\begin{array}{l}\text { Single maturity level at baseline } \\
\text { Food-based approach }\end{array}$ & $\begin{array}{l}\text { Dietary } \mathrm{Ca}>700 \mathrm{mg} / \mathrm{d} \\
\text { Pubertal status not reported at } \\
\text { follow-up }\end{array}$ \\
\hline Merrilees et al. (2000) $)^{(20)}$ & $\begin{array}{l}n 105 \text { girls aged } 15-16 \text { years } \\
\text { Dairy foods/placebo } 2 \text { years }\end{array}$ & Choice of dairy foods & Dietary $\mathrm{Ca}>700 \mathrm{mg} / \mathrm{d}$ \\
\hline Iuliano-Burns et al. (2003) $)^{(21)}$ & $\begin{array}{l}n 66 \text { children mean age } 8.8 \text { years } \\
\text { Milk minerals (in food)/placebo } \\
8.5 \text { months }\end{array}$ & Dietary $\mathrm{Ca}$ intake $<700 \mathrm{mg} / \mathrm{d}$ & $\begin{array}{l}\text { Pubertal status not reported post } \\
\text { Reduced sample size for Ca only } \\
\text { group }\end{array}$ \\
\hline Chan et al. (1995) $)^{(22)}$ & $\begin{array}{l}\text { n } 48 \text { girls aged } 9-13 \text { years } \\
\text { Dairy foods/placebo } \\
12 \text { months }\end{array}$ & Choice of dairy foods & $\begin{array}{l}\text { Dietary } \mathrm{Ca} \text { intake }>700 \mathrm{mg} / \mathrm{d} \\
\text { Pubertal status not reported post }\end{array}$ \\
\hline Cadogan et al. (1997) $)^{(23)}$ & $\begin{array}{l}n 80 \text { girls aged } 12 \text { years } \\
\text { Milk/placebo } \\
18 \text { months }\end{array}$ & Stratified by maturity level & Dietary Ca intake $>700 \mathrm{mg} / \mathrm{d}$ \\
\hline \multicolumn{4}{|l|}{ Adulthood } \\
\hline Kruger et al. (2006) $)^{(37)}$ & $\begin{array}{l}n 92 \text { women aged } 20-35 \text { years } \\
\text { Milk }(\mathrm{Ca}) / \mathrm{milk}(\mathrm{Ca}+\text { nutrients)/placebo } \\
16 \text { weeks }\end{array}$ & & $\begin{array}{l}\text { Short-term study } \\
\text { Contained multiple nutrients }\end{array}$ \\
\hline Kruger et al. $(2016)^{(38)}$ & $\begin{array}{l}n 136 \text { premenopausal women } \\
\text { Milk/milk ( } \mathrm{Ca}+\text { nutrients }) \\
12 \text { weeks }\end{array}$ & Dietary $\mathrm{Ca}<500 \mathrm{mg} / \mathrm{d}$ & $\begin{array}{l}\text { Short term (12 weeks) } \\
\text { Milk contained other nutrients }\end{array}$ \\
\hline Woo et al. $(2007)^{(39)}$ & $\begin{array}{l}n 441 \text { women aged } 20-35 \text { years } \\
\text { Milk powder/placebo } \\
2 \text { years }\end{array}$ & Dietary Ca intake $<500 \mathrm{mg} / \mathrm{d}$ & $\begin{array}{l}\text { Controls heavier and higher bone } \\
\text { mineral density } \\
\text { Compliance dropped to } 45 \% \text { in year } \\
2\end{array}$ \\
\hline \multicolumn{4}{|l|}{ Older age } \\
\hline Kruger et al. $(2016)^{(38)}$ & $\begin{array}{l}\text { n } 121 \text { postmenopausal women } \\
\text { Milk/milk }(\mathrm{Ca}+\text { nutrients }) \\
12 \text { weeks }\end{array}$ & Dietary $\mathrm{Ca}<500 \mathrm{mg} / \mathrm{d}$ & $\begin{array}{l}\text { Short term (12 weeks) } \\
\text { Compliance not reported }\end{array}$ \\
\hline Daly et al. (2006) $)^{(40)}$ & $\begin{array}{l}n 167 \text { men }>50 \text { years of age } \\
\text { Milk }(\mathrm{Ca}+\mathrm{D}) / \text { placebo } \\
2 \text { years }\end{array}$ & $85 \%$ compliance & $\begin{array}{l}\text { Fortified with } \mathrm{Ca} \text { and vitamin } \mathrm{D} \\
\text { Dietary } \mathrm{Ca}>800 \mathrm{mg} / \mathrm{d}\end{array}$ \\
\hline Moschonis et al. (2010) ${ }^{(41)}$ & $\begin{array}{l}\text { n } 66 \text { postmenopausal women } \\
\text { Dairy foods/placebo } \\
30 \text { months }\end{array}$ & Use of food & $\begin{array}{l}\text { Vitamin D added part way through } \\
\text { study } \\
\text { Total body scan divided into } \\
\text { region }\end{array}$ \\
\hline Kruger et al. (2010) ${ }^{(42)}$ & $\begin{array}{l}n 120 \text { postmenopausal women } \\
\text { Milk powder/placebo } \\
16 \text { weeks }\end{array}$ & $\begin{array}{l}98 \% \text { compliance } \\
\text { Dietary } \mathrm{Ca}<500 \mathrm{mg} / \mathrm{d}\end{array}$ & $\begin{array}{l}\text { Short-term study ( } 16 \text { weeks) } \\
\text { Milk fortified with other nutrients }\end{array}$ \\
\hline Kruger et al. (2012) ${ }^{(43)}$ & $\begin{array}{l}\text { n } 63 \text { postmenopausal women } \\
\text { Milk powder/placebo } \\
12 \text { weeks }\end{array}$ & $\begin{array}{l}98 \% \text { compliance } \\
\text { Dietary } \mathrm{Ca}<500 \mathrm{mg} / \mathrm{d}\end{array}$ & $\begin{array}{l}\text { Short-term study ( } 12 \text { weeks) } \\
\text { Milk fortified with other nutrients }\end{array}$ \\
\hline Chee et al. (2003) $)^{(45)}$ & $\begin{array}{l}n 200 \text { postmenopausal women } \\
\text { Milk }(\mathrm{Ca}) / \text { placebo } 2 \text { years }\end{array}$ & $\begin{array}{l}92 \% \text { compliance } \\
\text { Dietary } \mathrm{Ca}<500 \mathrm{mg} / \mathrm{d}\end{array}$ & $\begin{array}{l}\text { Groups not matched for bone } \\
\text { mineral density at baseline }\end{array}$ \\
\hline Lau et al. $(2002)^{(46)}$ & $\begin{array}{l}\text { Postmenopausal women } \\
\text { Milk }(\mathrm{Ca}) / \text { placebo } \\
3 \text { years }\end{array}$ & $\begin{array}{l}\text { Dietary } \mathrm{Ca}<500 \mathrm{mg} / \mathrm{d} \\
>90 \% \text { compliance }\end{array}$ & $\begin{array}{l}\text { Control group had higher baseline } \\
\text { bone mineral density }\end{array}$ \\
\hline
\end{tabular}


Table 1. Continued

\begin{tabular}{|c|c|c|c|}
\hline Reference & Study characteristics & Strengths & Limitations \\
\hline Bonjour et al. (2012) ${ }^{(49)}$ & $\begin{array}{l}n 71 \text { postmenopausal women } \\
\text { Cheese }(\mathrm{Ca}+\mathrm{D}) / \text { placebo } \\
6 \text { weeks }\end{array}$ & $\begin{array}{l}\text { Dietary } \mathrm{Ca}<600 \mathrm{mg} / \mathrm{d} \\
\text { Compliance rated as high (value not } \\
\text { reported) }\end{array}$ & Short-term study (6 weeks) \\
\hline Heaney et al. (1999) $)^{(50)}$ & $\begin{array}{l}n 204 \text { men and women }>55 \text { years } \\
\text { Milk/placebo } \\
12 \text { weeks }\end{array}$ & Dietary dairy food $<1.5$ servings & Short-term study (12 weeks) \\
\hline Heaney et al. (2002) ${ }^{(51)}$ & $\begin{array}{l}n 29 \text { postmenopausal women } \\
\text { Yogurt/placebo } \\
<2 \text { weeks }\end{array}$ & $\begin{array}{l}\text { Dietary Ca }<600 \mathrm{mg} / \mathrm{d} \\
99 \% \text { compliance }\end{array}$ & Short-term study $(<2$ weeks) \\
\hline Bonjour et al. $(2009)^{(59)}$ & $\begin{array}{l}\text { Thirty-seven institutionalised women, mean } \\
\text { age } 84 \text { years } \\
\text { Cheese }(\mathrm{Ca}+\text { vitamin } \mathrm{D}) \\
4 \text { weeks }\end{array}$ & $95 \%$ compliance & Short-term study (4 weeks) \\
\hline Recker et al. $1985^{(70)}$ & $\begin{array}{l}n 30 \text { postmenopausal women } \\
\text { Milk/placebo } \\
2 \text { years }\end{array}$ & 2-year intervention & Small sample size \\
\hline Bonjour et al. (2013) $)^{(76)}$ & $\begin{array}{l}n 59 \text { institutionalised women } \\
\text { Yogurt }(\mathrm{Ca}+\mathrm{D}) / \text { yogurt } \\
10 \text { weeks }\end{array}$ & $89 \%$ compliance & $\begin{array}{l}\text { Dietary } \mathrm{Ca}>700 \mathrm{mg} / \mathrm{d} \\
\text { Short term }(10 \text { weeks })\end{array}$ \\
\hline Iuliano-Burns et al. (2012) ${ }^{(77)}$ & $\begin{array}{l}n 84 \text { institutionalised older adults } \\
\text { Fortified foods (protein, } \mathrm{Ca} \text {, vitamin D)/ } \\
\text { placebo } \\
12 \text { months }\end{array}$ & $\begin{array}{l}\text { Food-based approach } \\
\text { Dietary } \mathrm{Ca}<600 \mathrm{mg} / \mathrm{d}\end{array}$ & $40 \%$ attrition \\
\hline
\end{tabular}

children with $\mathrm{Ca}$ intakes $>700 \mathrm{mg} / \mathrm{d}$, so depending on age (maturity status), participants were likely $\mathrm{Ca}$ replete $^{(13,14,17,19,20,22,23)}$. This issue was highlighted in a metaanalysis conducted by Huncharek et al. ${ }^{(27)}$. When all Ca-/dairy food-based intervention studies were pooled ( $n 12$ studies, with 2460 participants), no differences were observed in total body BMC accrual between treated children and controls (2 g; $95 \% \mathrm{CI}$ $-3,7 \mathrm{~g})^{(27)}$. However, baseline $\mathrm{Ca}$ intakes were low in three studies, which when analysed separately, a 50 g; 95\% CI 24, $77 \mathrm{~g}$ difference in total body BMC accrual between treatment and controls was observed. Two studies used milk fortified with $\mathrm{Ca}$ (approximately $600 \mathrm{mg}$ ) and one used fortified milk powder (approximately $840 \mathrm{mg} \mathrm{Ca})^{(27)}$. Protein intake was also augmented (10-30 g per supplement).

Efficacy of treatment is compromised with poor compliance $^{(28)}$. Of the twelve studies, seven reported compliance with dairy food-based interventions ranging from 60 to $100 \%{ }^{(13-19)}$. However, Gibbons et al. $^{(13)}$ reported $80 \%$ compliance in those that remained in the study, but over $50 \%$ of the study cohort withdrew. Lau et al. ${ }^{(16)}$ observed better compliance when supplemental dairy foods were administered at school (100\%) compared with at home (58\%), and, despite 100\% compliance with supplemental milk $(330 \mathrm{ml} / \mathrm{d})$, Du et $a l^{(15)}$ observed that habitual milk intake declined during the intervention period, resulting in milk intake of approximately $250 \mathrm{ml}$ daily during intervention, with no change observed in protein intake. Three studies reported $\mathrm{Ca}$ intake following supplementation, and all observed that habitual $\mathrm{Ca}$ intake and eating patterns reverted to pre-supplemented levels once intervention ceased $^{(12,13,20)}$. Two issues highlighted by these inconsistencies in compliance are sustainability of the dairy food intake following intervention and the ability to quantify the amount of dairy food required for a skeletal benefit to be observed.

The process of randomisation is to disperse traits (e.g. sex, maturity) equally between groups and to reduce their potential to bias results. Large dropout numbers, or uneven withdrawal from allocated groups, violate this randomisation process and may also compromise the power to detect changes with treatment. For example, Gibbons et al. ${ }^{(13)}$ reported a drop out rate of $53 \%$ during an 18-month dairy food-based intervention and reported no clinical benefits with dairy food supplementation. However, it is difficult to conclude whether the intervention was effective, as the baseline $\mathrm{Ca}$ intake and maturity status of the remaining participants were not reported, and whether the remaining number of participants provided sufficient power to detect differences if present.

The skeletal benefits of dairy foods may relate to the suppression of bone remodelling with $\mathrm{Ca}$, and/or the anabolic effect of stimulation of IGF-1 by protein or other synergistic benefits related to other constituents contained in dairy foods. The residual benefits observed by some authors would suggest an anabolic effect, while the reversal of benefits after cessation of dairy food supplementation suggests non-permanent changes perhaps due to suppression of bone remodelling in response to the elevated $\mathrm{Ca}$ intake, with remodelling returning to its previously higher rate once $\mathrm{Ca}$ intake is again lowered. Cadogan et al. ${ }^{(23)}$ in their previously mentioned 18-month dairy food-based intervention involving 12-year-old girls observed an increase in IGF-1 over time with Ca-fortified milk consumption $(P=0.023)$, but no change in bone markers. In a $7-\mathrm{d}$ trial involving 8-year-old boys that compared the daily consumption of 1.5 litres of skimmed milk ( $n$ 12) to the equivalent protein intake from low-fat meat ( $n$ 12), a $19 \%$ increase in IGF-1 and an $8 \%$ increase in insulin-like growth factor-binding protein 3 were observed with enhanced milk but not with meat intake ${ }^{(29)}$. The authors suggested the milk may have a direct effect on hepatic production of IGF-1 or via stimulation of growth hormone. However, total energy intake increased in the milk (10\%), but not in the meat group, and the milk group gained weight. Refeeding of protein-energy malnourished children also increases 
IGF-1, making it difficult to separate the effect of the increase in total energy compared with dairy food protein alone. The authors undertook a subsequent 7-d intervention involving 8year-old boys that compared the consumption of 1.5 litres/d of high-casein skimmed milk with a high-whey skimmed milk and observed a $15 \%$ increase in IGF-1 with casein but not with whey consumption ${ }^{(30)}$. The authors acknowledged that the casein content of milk is greater than whey content, so the effect may have been due to a higher protein intake.

\section{Dairy food intervention study design}

The features of study design and execution that improves study quality include controlling for maturity, participants having low habitual dairy food intake, good compliance with intervention and sufficient study participants with limited dropout. Cadogan et $a l^{(23)}$ was the only reported study to stratify participants by Tanner staging (controlling for maturity at onset) before randomisation and observed gains in total body BMC and higher IGF-1 levels with the consumption of the additional dairy foods. No group differences in sex hormone levels were observed, suggesting that the groups were matched for maturity. To separate the region-specific skeletal benefits of dairy foods before, during or after puberty, it would require sufficient numbers of participants at baseline, to enable treatment effects to be investigated within each level of maturity (pre-, peri- or post-puberty). A skeletal response is more likely in those with low habitual dairy food (Ca) intake, so efficacy is more likely demonstrated when participants are selected on this basis. Division of participants into high and low consumers after randomisation, may violate the randomisation process or reduce the power to detect benefits of dairy food supplementation if present. Compliance is highest when supplementation was administered at school, so may be a suitable avenue of administration ${ }^{(16)}$. The provision of a variety of products/tastes may assist with compliance as 'flavour fatigue' reduces intake over time. Ongoing monitoring of supplemental and habitual food intake is beneficial, as reductions in normal dietary dairy food intake in response to supplementation or erosion of compliance over time may reduce the potential to observe skeletal changes as the magnitude of the difference in dairy food intake between intervention and controls is compromised. Furthermore, standardising serving sizes and methods of recording dietary intakes would facilitate comparisons between studies.

\section{Bone maintenance in adulthood and loss in later life: can} dairy foods make a difference?

After puberty and leading into young adulthood, the bone continues to consolidate, albeit more slowly. Peak bone mass (PBM), which is defined as the amount of bone present at the end of skeletal maturation, is a major predictor of fracture risk in later life ${ }^{(31)}$. The attainment of PBM is thought to be achieved by approximately 30 years of age in both men and women, though PBM has been reported to be reached as early as the late teenage years or as late as the mid-30s depending on the skeletal site ${ }^{(32)}$.

Following the acquisition of PBM, bone continues to be remodelled, to remove and replace old and damaged bone. This process occurs at discrete foci on the bone surface. If within each focal point or basic multi-cellular unit (BMU) the amount of bone removed (resorption) and replaced (formation) is equal, then bone is neither lost nor gained. Bone loss is considered to commence some time during young adulthood due to a reduction in bone formation relative to bone resorption within each basic multicellular unit, so each BMU is effectively in a negative balance. Therefore, the number of BMU active at any point in time or the rate of remodelling would be a principal determinant of the rate of bone loss. Menopause in women is associated with increased remodelling intensity, or the number of remodelling sites initiated, due to the loss of oestrogen, which is marked by a rapid decrease in bone mineral density (BMD) ${ }^{(34)}$. Bone loss slows 3-5 years after menopause as a new steady state, but at a higher rate of remodelling, is achieved. Bone loss appears to be more gradual in men ${ }^{(33,34)}$

A principal driver of apparent changes in bone mass is the intensity of remodelling or the number of discrete remodelling sites initiated. $\mathrm{Ca}$ is considered a moderate suppressor of remodelling intensity, so supplementation reduces the number of remodelling sites initiated, resulting in an apparent increase in BMD. Alternatively Ca deficiency is associated with increased bone remodelling intensity and results in an apparent reduction in $\mathrm{BMD}^{(34)}$. This is evident in Ca supplementation trials where markers of bone turnover are lowered with supplementation, but a reversal of skeletal benefits observed when $\mathrm{Ca}$ (and vitamin D) supplementation is ceased, likely resulting from remodelling intensity returning to pre-supplemented levels ${ }^{(35)}$.

During young adulthood, if the rate of remodelling is low, then further rate suppression of remodelling would be relatively small and likely difficult to detect. Therefore, detection of skeletal changes in dairy food (or $\mathrm{Ca}$ ) supplementation trials in $\mathrm{Ca}-$ replete adults in whom remodelling rates are already low would likely be limited. During menopause when remodelling intensity is accelerated due to the rapid decline in oestrogen, the modest suppression of remodelling due to enhanced dairy food (or Ca) intake may also be challenging to detect. This was evident in the study by Dawson-Hughes \& Dallal ${ }^{(36)}$ who observed maintenance of BMD at the lumbar spine, femoral neck and radius with 2 years of Ca supplementation $(500 \mathrm{mg} / \mathrm{d})$ in women who consumed $<400 \mathrm{mg} / \mathrm{d}$ of $\mathrm{Ca}$, who were $>6$ years post-menopause, but not in women within 5 years after menopause. Most reported dairy food interventions include women at least 5 years post-menopause, with a fewer number of interventions involving premenopausal women and a limited number involving older men (Table 1$)^{(37-40)}$.

\section{Research design and skeletal effects of dairy food consumption}

Dairy food interventions involving adults require the same stringent research design as those involving children; sufficient 
sample size to detect changes if present, low baseline dairy food $(\mathrm{Ca})$ intake in participants, good compliance with intervention and limited dropouts to maintain the power to detect differences due to intervention. Some, but not all studies, fulfil these criteria. For example, despite including over 400 women with mean $\mathrm{Ca}$ intake of $<500 \mathrm{mg} / \mathrm{d}$ in their 2-year dairy foodbased intervention, Woo et al. ${ }^{(39)}$ observed no group differences in total body, spine or hip BMD using intentionto-treat analysis; compliance fell from $75 \%$ in the first year to $45 \%$ in the second year. A $<1 \%$ difference in spine BMD at 6 months, but no other time point, was observed using per protocol analysis, which may reflect a transient suppression of remodelling ${ }^{(39)}$. However, this cannot be confirmed as the reported serum C-terminal telopeptide of type 1 collagen (CTX) (bone resorption) changes were for all participants, not just those included in the per protocol analysis. In those studies that fulfil the design criteria, the majority have supplemented using dairy foods fortified with $\mathrm{Ca}$, vitamin $\mathrm{D}$ and/or other nutrients $^{(37-47)}$. While some of these nutrients are inherently found in dairy foods, the amounts are greater than naturally occurring; therefore, difficulties arise when discerning the contribution of naturally occurring compared with added nutrients to skeletal changes observed. In some cases, dairy foods are used as a vehicle to deliver non-dairy product-related nutrients ${ }^{(48)}$. Furthermore, while the vitamin $\mathrm{D}$ content of milk is relatively limited $(<0.05 \mu \mathrm{g} / 100 \mathrm{ml})$, vitamin D fortification is routine in some countries such as the USA and those in Scandinavia; therefore, the potential role of vitamin D in dairy foods needs to be considered especially when comparing studies from countries with and without routine fortification of dairy foods. The amount of vitamin D fortification and the size of a standard dairy food serving also vary between countries (and studies), which may potentially influence the magnitude of change in skeletal outcomes.

Short-term (1-16 weeks) dairy food-based interventions in adults consuming $<700 \mathrm{mg} / \mathrm{d}$ of $\mathrm{Ca}$ have demonstrated reductions in bone resorption (serum CTX and urinary $\mathrm{N}$ telopeptide) of between 6 and $40 \%$ within weeks of supplementation (Table 1$)^{(37,38,49)}$. Only two short-term studies used non-fortified dairy foods ${ }^{(50,51)}$. Longer-term (1-3 years) dairy food-based interventions that have reported changes in BMD as an outcome support the notion of suppression of remodelling with dairy food supplementation. Most studies reported significant differences in the rates of change to BMD at the total body, lumbar spine and femoral sites between controls and intervention by 12 months; however, the magnitude of the differences was maintained for the subsequent period of observation $(1-2 \text { years })^{(40,41,44,46)}$. The rates of change in BMD in the subsequent years were similar between intervention and controls; the slopes of change are parallel (Fig. 1) ${ }^{(41)}$. Although fracture outcomes are not reported, Johansson et al. ${ }^{(52)}$ in their meta-analysis of reference markers of bone turnover for prediction of fractures estimated that each standard deviation increase in CTX was associated with an $18 \%$ increased risk of fracture (hazard ratio: $1 \cdot 18,95 \%$ CI $1.08,1.29)$ and a $23 \%$ increased risk of hip fracture (hazard ratio: $1 \cdot 23,95 \%$ CI 1.04 , 1.47). Therefore, fracture risk reduction with dairy food supplementation is plausible.

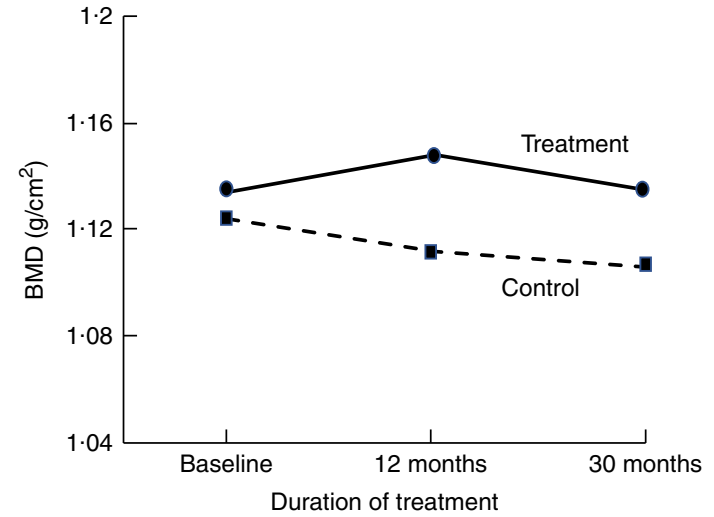

Fig. 1. Changes in total body bone mineral density (BMD) at 12 and 20 months in postmenopausal women supplemented with fortified dairy foods compared with non-supplemented controls. Data are adapted from Moschonis et al. $(2010)^{(41)}$

Dairy foods may potentially have anabolic qualities due to other constituents in dairy foods, such as protein, or $\mathrm{Ca}$ in combination with these components. Protein deficiency is associated with accelerated bone resorption and impaired bone formation, and protein supplementation in older adults increases IGF-1 and promotes Ca absorption, potentially slowing bone loss ${ }^{(53-55)}$. Therefore, in the presence of protein insufficiency, improvements in serum IGF-1 levels is likely with dairy food supplementation. Defining protein requirement in older adults is challenging, but intake of $1.0-1.2 \mathrm{~g} / \mathrm{kg}$ body weight are considered appropriate for healthy older adults, with levels of between 1.2 and $1.5 \mathrm{~g} / \mathrm{kg}$ body weight suggested for those with chronic or acute illnesses ${ }^{(56)}$.

Improvements in IGF-1 levels have been observed in older adults when supplemented with dairy foods. Manios et al. ${ }^{(57)}$ observed $13 \%$ higher IGF-1 levels at 5 months in dairy food supplemented compared with non-supplemented postmenopausal women. Baseline protein intake was $0.7 \mathrm{~g} / \mathrm{kg}$ body weight, and protein intake was augmented by approximately $12 \mathrm{~g}$. No group differences in IGF-1 were observed at 12 months $^{(57)}$. Kerstetter et $a l^{(58)}$ used a whey protein supplement in elderly men and women and observed approximately $6 \%$ higher IGF-1 levels in supplemented than in controls at 18 months but not at 9 months. Baseline protein intake was approximately $1.0 \mathrm{~g} / \mathrm{kg}$ body weight and protein intake increased by approximately $20 \mathrm{~g}$. Bonjour et $a l .{ }^{(59)}$ observed a $17 \%$ increase in IGF-1 in elderly institutionalised women after 1 month of supplementation using fortified soft cheese providing approximately $11 \mathrm{~g}$ of protein daily.

Higher BMD has been observed in intervention than in control participants 18-21 months after cessation of dairy food supplementation, which is suggestive of residual skeletal benefits of dairy food supplementation ${ }^{(44,60)}$. Daly et al. ${ }^{(60)}$ observed that 18 months after cessation of 2 years of dairy food supplementation in elderly males, the rate of change in BMD at the femoral neck favoured supplementation by $1 \cdot 4 \%$ (95\% CI $0 \cdot 1$, $2 \cdot 7, P<0.05)$. Ting et al. ${ }^{(44)}$ followed up postmenopausal female participants 21 months after cessation of 2 years of dairy food supplementation; and relative to baseline, the reduction in BMD observed at 45 months was less in the supplemented group than 


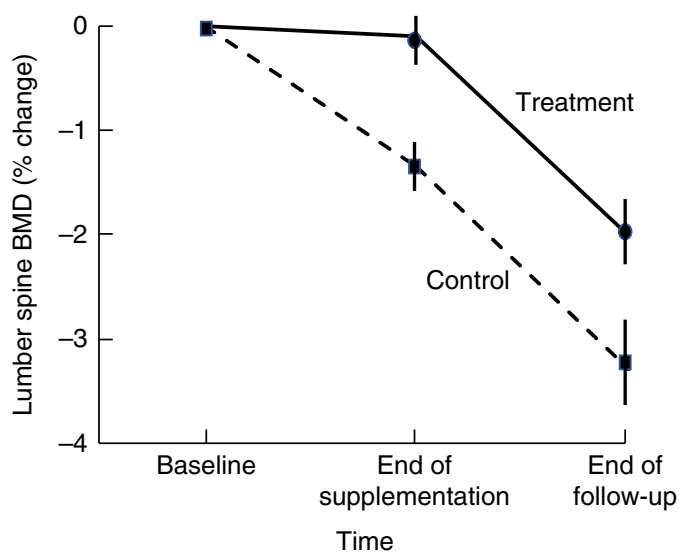

Fig. 2. Changes in lumbar spine bone mineral density (BMD) in postmenopausal women supplemented with fortified milk powder or not receiving supplementation for 24 and 21 months following the discontinuation of treatment. Data are adapted from Ting et al. $(2007)^{(44)}$

in controls at the lumbar spine $(-2 \cdot 01$ (SE 0.62) $v .-3 \cdot 29$ (SE 0.73)\%) and femoral neck $(0.44(\operatorname{se} 0.58) v .-1.49$ (SE 0.56) \%) (both $P<0.05)$. However, Daly et al. did not observe group differences in the rate of change in femoral neck BMD during the non-supplementation period, and Ting et al. ${ }^{(44)} \mathrm{did}$ not report the rate of change in BMD during the non-supplemented period but when plotted, rates of change to BMD were similar during this phase in the supplemented and controls (Fig. 2). Dietary Ca intake remained high during the non-supplemented period in the previously supplemented females (768(SD 424) $v$. 474 (sD 193) $\mathrm{mg} / \mathrm{d}, P<0.005)$.

\section{Dairy foods and fracture risk reduction: seeking the elusive} Holy Grail

Fractures are a public health problem that increase morbidity and healthcare costs ${ }^{(61)}$. By 2050, the number of people aged over 60 years globally will more than double, growing to over two billion, and constituting $25 \%$ of the population ${ }^{(62)}$. While longevity is increasing, morbidity remains unchanged, so the increasing proportion of the population that is elderly will disproportionately increase the burden imposed by morbidity and cost associated with fractures ${ }^{(63)}$. Hip fractures are the most costly, with the number of hip fractures estimate to be between 4.5 and 6.3 million by $2050^{(64,65)}$. Drug therapy for all older adults is not feasible, so methods are needed that are efficacious, safe, widely available and inexpensive. This public health approach aims to reduce fracture risk modestly but in the entire elderly population ${ }^{(66)}$. Low intake of $\mathrm{Ca}$ and protein increase fracture risk, are common in the elderly and are amenable to treatment ${ }^{(67,68)}$. Increasing dairy food (i.e. milk, cheese, yogurt) consumption to recommended levels can effectively remedy protein and Ca deficiencies and fulfil the requirement of a safe, widely available and inexpensive means of intervention.

What is missing is the demonstration of anti-fracture efficacy, not because it is not plausible that adequate dairy food consumption may reduce fracture risk, but because to date no randomised controlled, prospective study investigating the anti- fracture efficacy of dairy foods have been undertaken. The demonstration of anti-fracture efficacy from Ca supplementation (not dietary sources of $\mathrm{Ca}$ ) is inconsistent, likely due to the same limitations observed in dairy food-based studies; participants not being $\mathrm{Ca}$ deficient, poor compliance, high dropout rates and insufficient number of participants and study duration for enough fracture events to occur for efficacy to be detectable ${ }^{(33)}$. Sub-analyses of these trials are suggestive of antifracture efficacy. When the effect of $\mathrm{Ca}$ supplementation was tested in subgroups with intake $<800 \mathrm{mg} / \mathrm{d}$, a $20 \%$ reduction in fracture risk was observed and reduced fracture rates have been observed in post hoc analyses in those with low Ca intake in the community and in aged-care ${ }^{(69-71)}$.

To demonstrate the anti-fracture efficacy of dairy food consumption, the same stringent design criteria highlighted earlier needs to be applied: large sample size, low baseline $\mathrm{Ca}$ /dairy food intakes, good compliance and limited dropouts. Such a trial in the community would be difficult to conduct and likely not feasible as the numbers needed to treat to prevent a fracture event would be large, compliance difficult to monitor and verifying low-trauma fractures problematic as selfreporting and recall of fracture events are often unreliable especially in those with cognitive impairment ${ }^{(72)}$. The setting in which the successful execution of a dairy food intervention is most probable is in institutionalised elderly. In this group, fracture risk is the highest compared with any other group in the community, nutritional deficiencies prevail, food intake (and compliance) can be closely monitored and fractures recorded as the setting in well controlled ${ }^{(73,74)}$. The success of the landmark Ca and vitamin D fracture trial was likely driven by the low Ca intake and high levels of vitamin D deficiency in participants ${ }^{(75)}$.

Dairy food-based interventions conducted in this setting to date are promising (Table 1). Bonjour et al. ${ }^{(76)}$ compared the efficacy of vitamin D- (10 $\mu \mathrm{g})$ and Ca-fortified (800 mg) yogurt to regular yogurt (Ca content $280 \mathrm{mg}$ ) over $56 \mathrm{~d}$ in sixty vitamin Ddeficient elderly institutionalised women and observed parathyroid hormone and CTX were $20 \%(P<0.001)$ and $8 \%$ $(P<0.05)$ lower, respectively, with fortification. A $42 \%(\mathrm{OR}=$ $0.58,95 \%$ CI $0.44,0.78, P<0.001)$ reduction in the number of institutionalised elderly who fell was observed after 12 months of supplementation using a dairy food-based protein, Ca and vitamin D supplement in 813 aged-care residents ${ }^{(77)}$. The study was not powered to detect fractures. Using a dairy food-based approach in the aged-care setting, dairy food intake was increased from two to four servings daily, resulting in a doubling of $\mathrm{Ca}$ intake $(679 \mathrm{mg}, P<0.0001)$, the consumption of $25 \mathrm{~g} / \mathrm{d}$ more protein daily $(P<0 \cdot 0001)$ and residents meeting protein and $\mathrm{Ca}$ requirements, which remained below the recommended intake levels in controls ${ }^{(78)}$.

The existing evidence from dairy food intervention trials is suggestive of an anti-fracture efficacy of enhanced dairy food consumption. Given the widespread availability of dairy foods, it is a reasonable and potentially feasible public health approach to fracture prevention. Modelling of the economic impact of dairy food supplementation to reduce fractures indicates that it is cost-effective in postmenopausal women aged over 70 years, particularly in those with low $\mathrm{Ca}$ intake 
$(<600 \mathrm{mg} / \mathrm{d})^{(79)}$. These public health approaches need concerted consideration as the population ages and the proportion of high-risk older adults increases. However, until a welldesigned dairy food intervention trial is conducted, the antifracture benefits of dairy food consumption will continue to be based on conjecture.

\section{Acknowledgements}

Funding was provided by the Dairy Council (www.milk.co.uk). The Dairy Council GB had no role in the writing of this manuscript.

S. I. and T. R. H. were responsible for the preparation and writing of this review.

S. I. receives research funding support from Dairy Australia, California Dairy Research Foundation, National Dairy Council, Aarhus University Hospital and Danish Dairy Research Foundation, Fonterra Co-operative Group Ltd, Dutch Dairy Association, Dairy Council of California, Dairy Farmers of Canada and the Centre National Interprofessionnel de l'Economie Laitiere. T. R. H. has received consultancy fees and honoraria from the Dairy Council GB.

\section{References}

1. Bonnard GD (1968) Cortical thickness and diaphysial diameter of the metacarpal bones from the age of three months to eleven years. Helv Paediatr Acta 23, 445-463.

2. Forest MG, Sizonenko PC, Cathiard AM, et al. (1974) Hypophyso-gonadal function in humans during the first year of life. 1. Evidence for testicular activity in early infancy. J Clin Invest 53, 819-828.

3. Maccoby EE, Doering CH, Jacklin CN, et al. (1979) Concentrations of sex hormones in umbilical-cord blood: their relation to sex and birth order of infants. Child Dev 50, 632-642.

4. Garn S (1970) The Earlier Gain and Later Loss of Crtical Bone: Nutritional Perspectives, pp. 3-120. Springfield, IL: Charles C. Thomas.

5. Clark PA \& Rogol AD. (1996) Growth hormones and sex steroid interactions at puberty. Endocrinol Metab Clin North Am 25, 665-681.

6. Gasser T, Kneip A, Binding A, et al. (1991) The dynamics of linear growth in distance, velocity and acceleration. Ann Hum Biol 18, 187-205.

7. Iuliano-Burns S, Hopper J \& Seeman E (2009) The age of puberty determines sexual dimorphism in bone structure: a male/female co-twin control study. J Clin Endocrinol Metab 94, 1638-1643.

8. Bates B, Lennox A, Prentice A, et al. (2014) National Diet and Nutrition Survey Results from Years 1, 2, 3 and 4 (Combined) of the Rolling Programme (2008/2009-2011/2012). London: PHE Publications.

9. Cribb VL, Northstone K, Hopkins D, et al. (2015) Sources of vitamin $\mathrm{D}$ and calcium in the diets of preschool children in the UK and the theoretical effect of food fortification. J Hum Nutr Diet 28, 583-592.

10. Gao X, Wilde PE, Lichtenstein AH, et al. (2006) Meeting adequate intake for dietary calcium without dairy foods in adolescents aged 9 to 18 years (National Health and Nutrition Examination Survey 2001-2002). J Am Diet Assoc 106, 1759-1765.

11. O'Neil CE, Nicklas TA \& Fulgoni VL III (2018) Food sources of energy and nutrients of public health concern and nutrients to limit with a focus on milk and other dairy foods in children 2 to 18 years of age: National Health and Nutrition Examination Survey, 2011-2014. Nutrients 10, E1050.

12. Zhu K, Greenfield H, Du X, et al. (2008) Effects of two years' milk supplementation on size-corrected bone mineral density of Chinese girls. Asia Pacific J Clin Nutr 17, Suppl. 1, 147-150.

13. Gibbons MJ, Gilchrist NL, Frampton C, et al. (2004) The effects of a high calcium dairy food on bone health in pre-pubertal children in New Zealand. Asia Pac J Clin Nutr 13, 341-347.

14. Iuliano-Burns S, Wang XF, Evans A, et al. (2006) Skeletal benefits from calcium supplementation are limited in children with calcium intakes near $800 \mathrm{mg}$ daily. Osteoporos Int 17, 1794-1800.

15. Du X, Zhu K, Trube A, et al. (2004) School-milk intervention trial enhances growth and bone mineral accretion in Chinese girls aged 10-12 years in Beijing. Br J Nutr 92, 159-168.

16. Lau EM, Lynn H, Chan YH, et al. (2004) Benefits of milk powder supplementation on bone accretion in Chinese children. Osteoporos Int 15, 654-658.

17. Chevalley T, Bonjour JP, Ferrari S, et al. (2005) Skeletal site selectivity in the effects of calcium supplementation on areal bone mineral density gain: a randomized, double-blind, placebo-controlled trial in prepubertal boys. J Clin Endocrinol Metab 90, 3342-3349.

18. Cheng S, Lyytikainen A, Kroger H, et al. (2005) Effects of calcium, dairy product, and vitamin D supplementation on bone mass accrual and body composition in 10-12-y-old girls: a 2-y randomized trial. Am J Clin Nutr 82, 1115-1126.

19. Bonjour JP, Carrie AL, Ferrari S, et al. (1997) Calcium-enriched foods and bone mass growth in prepubertal girls: a randomized, double-blind, placebo-controlled trial. J Clin Invest 99 , $1287-1294$

20. Merrilees MJ, Smart EJ, Gilchrist NL, et al. (2000) Effects of diary food supplements on bone mineral density in teenage girls. Eur J Nutr 39, 256-262.

21. Iuliano-Burns S, Saxon L, Naughton G, et al. (2003) Regional specificity of exercise and calcium during skeletal growth in girls: a randomised controlled trial. J Bone Miner Res 18, $156-162$.

22. Chan GM, Hoffman K \& McMurry M (1995) Effects of dairy products on bone and body composition in pubertal girls. $J$ Pediatr 126, 551-556.

23. Cadogan J, Eastell R, Jones N, et al. (1997) Milk intake and bone mineral acquisition in adolescent girls: randomised, controlled intervention trial. BMJ 315, 1255-1260.

24. Bailey DA, Martin AD, McKay HA, et al. (2000) Calcium accretion in girls and boys during puberty: a longitudinal analysis. J Bone Miner Res 15, 2245-2250.

25. Weaver CM, Martin BR, Plawecki KL, et al. (1995) Differences in calcium metabolism between adolescent and adult females. Am J Clin Nutr 61, 577-581.

26. Wastney ME, Ng J, Smith D, et al. (1996) Differences in calcium kinetics between adolescent girls and young women. Am J Physiol 271, 208-216.

27. Huncharek M, Muscat J \& Kupelnick B (2008) Impact of dairy products and dietary calcium on bone-mineral content in children: results of a meta-analysis. Bone 43, 312-321.

28. Compston JE \& Seeman E (2006) Compliance with osteoporosis therapy is the weakest link. Lancet 368, 973-974.

29. Hoppe C, Molgaard C, Juul A, et al. (2004) High intakes of skimmed milk, but not meat, increase serum IGF-I and IGFBP-3 in eight-year-old boys. Eur J Clin Nutr 58, 1211-1216.

30. Hoppe C, Molgaard C, Dalum C, et al. (2009) Differential effects of casein versus whey on fasting plasma levels of insulin, IGF-1 and IGF-1/IGFBP-3: results from a randomized 
7-day supplementation study in prepubertal boys. Eur J Clin Nutr 63, 1076-1083

31. Bonjour JP, Chevalley T, Ferrari S, et al. (2009) The importance and relevance of peak bone mass in the prevalence of osteoporosis. Salud Publica Mex 51, Suppl. 1, S5-S17.

32. Baxter-Jones AD, Faulkner RA, Forwood MR, et al. (2011) Bone mineral accrual from 8 to 30 years of age: an estimation of peak bone mass. J Bone Miner Res 26, 1729-1739.

33. Seeman E (2010) Evidence that calcium supplements reduce fracture risk is lacking. Clin J Am Soc Nephrol 5, Suppl. 1, S3-S11.

34. Seeman E, Bianchi G, Khosla S, et al. (2006) Bone fragility in men - where are we? Osteoporos Int 17, 1577-1583.

35. Dawson-Hughes B, Harris SS, Krall EA, et al. (2000) Effect of withdrawal of calcium and vitamin D supplements on bone mass in elderly men and women. Am J Clin Nutr $\mathbf{7 2}$, 745-750.

36. Dawson-Hughes B \& Dallal GE (1990) Effect of radiographic abnormalities on rate of bone loss from the spine. Calcif Tissue Int 46, 280-281.

37. Kruger MC, Booth CL, Coad J, et al. (2006) Effect of calcium fortified milk supplementation with or without vitamin $\mathrm{K}$ on biochemical markers of bone turnover in premenopausal women. Nutrition 22, 1120-1128.

38. Kruger MC, Chan YM, Kuhn-Sherlock B, et al. (2016) Differential effects of calcium- and vitamin D-fortified milk with FOS-inulin compared to regular milk, on bone biomarkers in Chinese pre- and postmenopausal women. Eur J Nutr $\mathbf{5 5}$ 1911-1921.

39. Woo J, Lau W, Xu L, et al. (2007) Milk supplementation and bone health in young adult chinese women. $J$ Womens Health 16, 692-702.

40. Daly RM, Brown M, Bass S, et al. (2006) Calcium- and vitamin $\mathrm{D}_{3}$-fortified milk reduces bone loss at clinically relevant skeletal sites in older men: a 2-year randomized controlled trial. J Bone Miner Res 21, 397-405.

41. Moschonis G, Katsaroli I, Lyritis GP, et al. (2010) The effects of a 30-month dietary intervention on bone mineral density: the Postmenopausal Health Study. Br J Nutr 104, 100-107.

42. Kruger MC, Schollum LM, Kuhn-Sherlock B, et al. (2010) The effect of a fortified milk drink on vitamin $\mathrm{D}$ status and bone turnover in post-menopausal women from South East Asia. Bone 46, 759-767.

43. Kruger MC, Ha PC, Todd JM, et al. (2012) High-calcium, vitamin $\mathrm{D}$ fortified milk is effective in improving bone turnover markers and vitamin D status in healthy postmenopausal Chinese women. Eur J Clin Nutr 66, 856-861.

44. Ting GP, Tan SY, Chan SP, et al. (2007) A follow-up study on the effects of a milk supplement on bone mineral density of postmenopausal Chinese women in Malaysia. J Nutr Health Aging 11, 69-73

45. Chee WS, Suriah AR, Chan SP, et al. (2003) The effect of milk supplementation on bone mineral density in postmenopausal Chinese women in Malaysia. Osteoporos Int 14, 828-834.

46. Lau EM, Lynn H, Chan YH, et al. (2002) Milk supplementation prevents bone loss in postmenopausal Chinese women over 3 years. Bone 31, 536-540.

47. Chen Y, Xiao Y, Xie B, et al. (2016) Effect of milk powder supplementation with different calcium contents on bone mineral density of postmenopausal women in northern China: a randomized controlled double-blind trial. Calcif Tissue Int 98, 60-66.

48. Mardones F, Urrutia MT, Villarroel L, et al. (2008) Effects of a dairy product fortified with multiple micronutrients and omega-3 fatty acids on birth weight and gestation duration in pregnant Chilean women. Public Health Nutr 11, 30-40.
49. Bonjour JP, Benoit V, Rousseau B, et al. (2012) Consumption of vitamin D-and calcium-fortified soft white cheese lowers the biochemical marker of bone resorption TRAP 5b in postmenopausal women at moderate risk of osteoporosis fracture. J Nutr 142, 698-703.

50. Heaney RP, McCarron DA, Dawson-Hughes B, et al. (1999) Dietary changes favorably affect bone remodeling in older adults. J Am Diet Assoc 99, 1228-1233.

51. Heaney RP, Rafferty K \& Dowell MS (2002) Effect of yogurt on a urinary marker of bone resorption in postmenopausal women. J Am Dietetic Assoc 102, 1672-1674.

52. Johansson H, Oden A, Kanis JA, et al. (2014) A meta-analysis of reference markers of bone turnover for prediction of fracture. Calcif Tissue Int 94, 560-567.

53. Schurch MA, Rizzoli R, Slosman D, et al. (1998) Protein supplements increase serum insulin-like growth factor-I levels and attenuate proximal femur bone loss in patients with recent hip fracture. A randomized, double-blind, placebocontrolled trial. Ann Intern Med 128, 801-809.

54. Volkert D (2011) The role of nutrition in the prevention of sarcopenia. Wien Med Wochenschr 161, 409-415.

55. Gaffney-Stomberg E, Insogna KL, Rodriguez NR, et al. (2009) Increasing dietary protein requirements in elderly people for optimal muscle and bone health. J Am Geriatr Soc 57, 1073-1079

56. Bauer J, Biolo G, Cederholm T, et al. (2013) Evidence-based recommendations for optimal dietary protein intake in older people: a position paper from the PROT-AGE Study Group. I Am Med Dir Assoc 14, 542-559.

57. Manios Y, Moschonis G, Panagiotakos DB, et al. (2009) Changes in biochemical indices of bone metabolism in postmenopausal women following a dietary intervention with fortified dairy products. J Hum Nutr Diet 22, 156-165.

58. Kerstetter JE, Bihuniak JD, Brindisi J, et al. (2015) The effect of a whey protein supplement on bone mass in older Caucasian adults. J Clin Endocrinol Metab 100, 2214-2222.

59. Bonjour JP, Benoit V, Pourchaire O, et al. (2009) Inhibition of markers of bone resorption by consumption of vitamin $\mathrm{D}$ and calcium-fortified soft plain cheese by institutionalised elderly women. Br J Nutr 102, 962-966.

60. Daly RM, Petrass N, Bass S, et al. (2008) The skeletal benefits of calcium- and vitamin $\mathrm{D}_{3}$-fortified milk are sustained in older men after withdrawal of supplementation: an 18-mo followup study. Am J Clin Nutr 87, 771-777.

61. Sanders KM, Nicholson GC, Ugoni AM, et al. (1999) Health burden of hip and other fractures in Australia beyond 2000. Projections based on the Geelong Osteoporosis Study. Med J Aust 170, 467-470.

62. United Nations (2012) Population ageing and development: ten years after Madrid. Department of Economic and Social Affairs PD. Contract no. 2012/4.

63. Christensen K, Doblhammer G, Rau R, et al. (2009) Ageing populations: the challenges ahead. Lancet 374, 1196-1208.

64. Gullberg B, Johnell O \& Kanis JA (1997) World-wide projections for hip fracture. Osteoporos Int 7, 407-413.

65. Cooper C, Campion G \& Melton LJ 3rd (1992) Hip fractures in the elderly: a world-wide projection. Osteoporos Int $\mathbf{2}$, 285-289.

66. Rose G (2001) Sick individuals and sick populations. 1985. Bull World Health Organ 79, 990-996.

67. FAO/WHO (2004) Vitamin and Mineral Requirements in Human Nutrition, 2nd ed. Geneva: World Health Organization.

68. Iuliano S, Poon S, Wang X, et al. (2017) Dairy food supplementation may reduce malnutrition risk in institutionalised elderly. Br J Nutr 117, 142-147. 
69. Dawson-Hughes B, Dallal GE, Krall EA, et al. (1990) A controlled trial of the effect of calcium supplementation on bone density in postmenopausal women. New Engl J Med 323 , 878-883.

70. Recker RR, Hinders S, Davies KM, et al. (1996) Correcting calcium nutritional deficiency prevents spine fractures in elderly women. J Bone Miner Res 11, 1961-1966.

71. Abbasi AA \& Rudman D (1994) Undernutrition in the nursing home: prevalence, consequences, causes and prevention. Nutr Rev 52, 113-122.

72. Ismail AA, O'Neill TW, Cockerill W, et al. (2000) Validity of self-report of fractures: results from a prospective study in men and women across Europe. EPOS Study Group. European Prospective Osteoporosis Study Group. Osteoporos Int 11, 248-254.

73. Woods J, Walker K, Iuliano-Burns S, et al. (2009) Malnutrition on the menu: nutritional status of institutionalised elderly Australians in low-level care. J Nutr Health Aging 13, 693-698.

74. Sanders KM, Seeman E, Ugoni AM, et al. (1999) Age- and gender-specific rate of fractures in Australia: a populationbased study. Osteoporos Int 10, 240-247.
75. Chapuy MC, Arlot ME, Duboeuf F, et al. (1992) Vitamin $\mathrm{D}_{3}$ and calcium to prevent hip fractures in the elderly women. New Engl J Med 327, 1637-1642.

76. Bonjour JP, Benoit V, Payen F, et al. (2013) Consumption of yogurts fortified in vitamin $\mathrm{D}$ and calcium reduces serum parathyroid hormone and markers of bone resorption: a double-blind randomized controlled trial in institutionalized elderly women. J Clin Endocrinol Metab 98, 2915-2921.

77. Iuliano-Burns S, Woods J, King K, et al. (2012) A dairy-based protein, calcium and vitamin $\mathrm{D}$ supplement reduces falls and femoral neck bone loss in aged care residents: a cluster randomised trial. J Aging Res Clin Pract 2, 141-146.

78. Iuliano S, Woods J \& Robbins J (2013) Consuming two additional serves of dairy food a day significantly improves energy and nutrient intakes in ambulatory aged care residents: a feasibility study. J Nutr Health Aging 17, 509-513.

79. Ethgen O, Hiligsmann M, Burlet N, et al. (2015) Public health impact and cost-effectiveness of dairy products supplemented with vitamin D in prevention of osteoporotic fractures. Arch Public Health 73, 48. 